\title{
THE EVOLUTION OF THE FRESHWATER RACES OF THE ATLANTIC SALMON (SALMO SALAR L) IN EASTERN NORTH AMERICA
}

\author{
G. Power*
}

\begin{abstract}
The life cycle of the Atlantic salmon (Salmo salar L.) is typically divided 1 between freshwater and marine environments. Spawning occurs in rivers and the juvenile salmon, known as parr, remain in this habitat for from 1 to 7 years before changing into smolts and migrating to the sea. Little is known of the marine life of the salmon except that it usually occupies a period of from 1 to 3 years, during which growth is extremely rapid. Following this phase the fish return to the rivers of their origin, attain full sexual maturity, and spawn, thus completing the cycle.
\end{abstract}

All Atlantic salmon do not conform to this pattern, however, and a number of forms, known as Ouananiche, Sebago salmon, landlocked salmon, etc., are recognized, which complete their life cycle entirely' in fresh water. These freshwater races are exceedingly widespread in eastern North America. Jordan and Evermann (1896) recognized two types and, although they were indistinguishable morphologically, listed them as subspecies of the Atlantic salmon, Salmo salar sebago and Salmo salar ouananiche. Wilder (1947) was unable to find any morphological criterion for separating the Sebago salmon from the Atlantic salmon. The most obvious distinction between the Atlantic salmon and its freshwater races is that the latter do not migrate to sea at any stage in the life cycle, although in many instances they are not prevented from doing so by other than physiological barriers.

Sebago salmon inhabit lakes that are distributed along the fringe of the presumed maximum extent of the Pleistocene glaciation in eastern North America. A population, now extinct, inhabited Lake Ontario until the beginning of this century (Huntsman, 1944). Other populations are found in lakes in southern Quebec, New Hampshire, New York, Maine, and New Brunswick (Greeley, 1948). Their growth pattern is similar to that of typical sea-going salmon, slow parr growth being readily distinguishable from a faster post-smolt-stage growth. Mature adults not infrequently attain weights of up to 15 pounds.

The Ouananiche reportedly have their area of distribution centered in the vicinity of Lake St. John, Quebec, but are much more widespread than

\footnotetext{
* Assistant Professor of Zoology, Waterloo College, Waterloo, Ont.
} 
is generally realized. They are found above impassable falls in many rivers flowing from the north into the Gulf of St. Lawrence. Farther north they are reported to be plentiful in both branches of the Hamilton River above Grand Falls, common in Lake Michikamau at the head of Northwest River, plentiful in the upper George River and in the Koksoak River below Lake Kaniapiskau and above Limestone Falls (Low, 1895). The fish have been taken in lakes in the centre of the Labrador Plateau near Schefferville (Knob Lake), and at Lac Aigneau in a tributary of the Larch River, again above impassable falls. In the Ouananiche growth is much slower, postsmolt-stage growth being often indistinguishable from parr growth. Mature adults average 2 to 3 pounds in weight and rarely attain 6 pounds. On the whole they are slimmer and more active than the heavier, deeper-bodied Sebago and tend to be more juvenile in appearance and proportions.

The origin and the distribution of the freshwater salmon can only be considered with reference to the Pleistocene glaciation and the events which followed this period. With the development of the ice sheets life zones moved southward ahead of the advancing glaciers. Indications are that the tundra zone immediately in front of the ice sheets was not very extensive and that the botanical zones typical of the north temperate and subarctic regions were restricted in width. Assuming that the environmental tolerances of the Atlantic salmon were at that time similar to what they are today, salmon would inhabit rivers as far north as the tundra zone. With the retreat and disappearance of the Laurentian ice sheets, life zones moved north again and rivers and lakes from which fish had been eliminated became inhabitable once more. The amelioration of the post-pleistocene climate was probably not a steady change in one direction, but a fluctuating moderation, warmer periods being interspersed with colder. Salmon recolonizing the rivers at that time would periodically be subjected to unfavourable climatic conditions coupled with instability in their environment due to changes of water-level resulting from variations in the rate of melting of receding glaciers.

Recent work by the author on the salmon populations inhabiting the George and Koksoak rivers, which are among the northernmost rivers inhabited by salmon on this continent at the present time, indicates the changes that might be expected in salmon populations exposed to a severely cold climate. Before conjecturing what these changes might involve, certain modifications in the life cycle of the salmon in these northern rivers must be mentioned.

That the length of the parr life of the salmon changes with the latitude is well known. In the south of the range parr life is short, 1 year often being sufficient for the young salmon to attain the smolt stage. The length of the parr life increases toward the north so that frequently 3 or 4 years are spent in the rivers prior to metamorphosis and migration. This increase in the duration of the parr stage is seen in its extreme development on the northern fringe of the range, where the average length of parr life is between 4 and 5 years and parr 7 years old are by no means rare. The 
longer duration of parr life in the north is usually attributed to slow growth originating in poor feeding conditions, this combines with the fact that the parr have to attain a certain physiological condition, in which size appears to be a factor, before they can undergo metamorphosis.

In the George and Koksoak rivers parr growth is slow only if expressed in terms of growth per annum. If it is calculated on the basis of growth per day during the growing season it is as good, or even better, then growth farther south. The short growing season, which in these latitudes is reduced to some 10 to 14 weeks, is responsible for the small annual increments of growth shown by these fish. Another interesting observation is that the size at migration of the smolts increases in these northern rivers. This is contrary to what has been reported to happen in Great Britain and Norway where the length of parr life shows a very definite increase toward the north, whereas the size at migration generally remains fairly constant or tends to decrease. The average size in the migrating smolt population of the George River is between 21 and $22 \mathrm{cms}$. and figures for the Koksoak River would be of the same order. This is considerably larger than the size of smolts at migration from rivers farther south in Canada, where the range is usually from 12 to $16 \mathrm{cms}$.

This retardation in the juvenile stages is not evident in the post-smolt stages of the northern salmon. Once they have left the rivers their growth is as vigorous as that of salmon from much more southerly latitudes, a fact that strongly supports the idea first expressed by Menzies (1949) that some centralized feeding ground for salmon exists somewhere in the North Atlantic.

Not only is smolt metamorphosis in the George and Koksoak rivers delayed until a relatively large size is attained, but many anomalies in the process are evident. Under normal circumstances metamorphosis occurs early in the spring and the smolts migrate to the sea during the same season. In the north the same period is apparently too short for all this to be accomplished, and in the Koksoak River large numbers of fish in its upper reaches shoal up and transform into smolts in the fall before the year of migration. Smolts can be taken in these rivers at all seasons of the year; however, the majority of the smolts that migrate to the sea in any particular year do so in June or July, which is spring in those latitudes. A number of fish, which appear to have failed to migrate, are present in these rivers. A fish taken in the Larch River, a tributary of the Koksoak, $29 \mathrm{cms}$. in length, and possibly two others, $27 \mathrm{cms}$. in length, fall into this category, as do fish taken in the George River, $29.5 \mathrm{cms}$., $32 \mathrm{cms}$., and $36 \mathrm{cms}$., in length. If such fish became sexually mature a potential freshwater population of salmon could become established.

There is little difficulty in visualizing this for the males, many of which become sexually mature as parr under normal circumstances. This holds true for the northern populations in which, besides sexually mature male parr, sexually mature male smolts are also found. Female parr, however, have never been taken in a sexually mature condition. Recent work by 
Hoar (1953) and Fontaine (1954) on smolt metamorphosis and migration has stressed the importance of the neuro-endocrine changes, which are associated with the process and alter the internal environment in response to, or in anticipation of, migratory stimuli. If, under conditions of extreme cold, development of a susceptibility to migratory stimuli is retarded more than the rate of sexual development, then the females could mature prior to migration. Changes in this direction are suggested by the presence in northern populations of the exceptional fish already mentioned, which comprise about 1 per cent of the total juvenile population. Once the females begin to mature sexually as parr, the sea-phase of the salmon's life cycle would be quickly eliminated and evolutionary pressures would favour earlier maturation and a faster reproduction rate. Thus on the northern fringes of the range of the salmon, during periods in which the climate deteriorated, populations would be produced containing a relatively high percentage of fish that completed the life cycle entirely within fresh water.

In order to be perpetuated as a "race" these fish must become isolated from the normal migratory forms; this can have happened as a result of the gradual rising of the land after glaciation and the falling of the levels of many of the lakes and rivers, rendering the head waters inaccessible to migratory fish. Where the freshwater form did not become isolated from the migratory, the former was gradually assimilated into the latter's population as a result of the interbreeding that took place between the two as the climate ameliorated once more and the migratory form became again predominant in the population.

Any tendency of the freshwater salmon population, once isolated, to regain their migratory behaviour and go to sea would be suppressed at the outset, because those members that did migrate would have been prevented from returning by the physical barriers that caused the original isolation of the population.

Analysis of the growth of freshwater salmon populations inhabiting Lac Aigneau, $57^{\circ} 13^{\prime} \mathrm{N} .70^{\circ} 08^{\prime} \mathrm{W}$., and Astray Lake, $54^{\circ} 35^{\prime} \mathrm{N}$. $66^{\circ} 30^{\prime} \mathrm{W}$. (Fig. 1 ), shows the form that the growth pattern of such salmon takes under cold conditions. The growth curve of the Aigneau salmon is regular and shows no marked change in rate at any stage. The scales of approximately 50 per cent of the salmon from Astray Lake show a similar type of growth without evidence of variation in growth rate between parr and post-smolt stages, whereas the remainder indicate that a slight acceleration occurs after 3 or 4 years. This increase, however, is not of sufficient magnitude to influence greatly the calculated mean lengths on the completion of each winter band, given in Table 2, with the result that the growth curve appears regular.

This is the type of growth that would be expected in a newly evolved race of freshwater salmon inhabiting a region in which the climate was fairly severe and it is retained in the populations still living under such conditions. The races of freshwater salmon that became isolated in regions that now have relatively mild climates exhibit growth patterns similar to those of sea-going salmon. Even in Lake St. John, which is the area from 


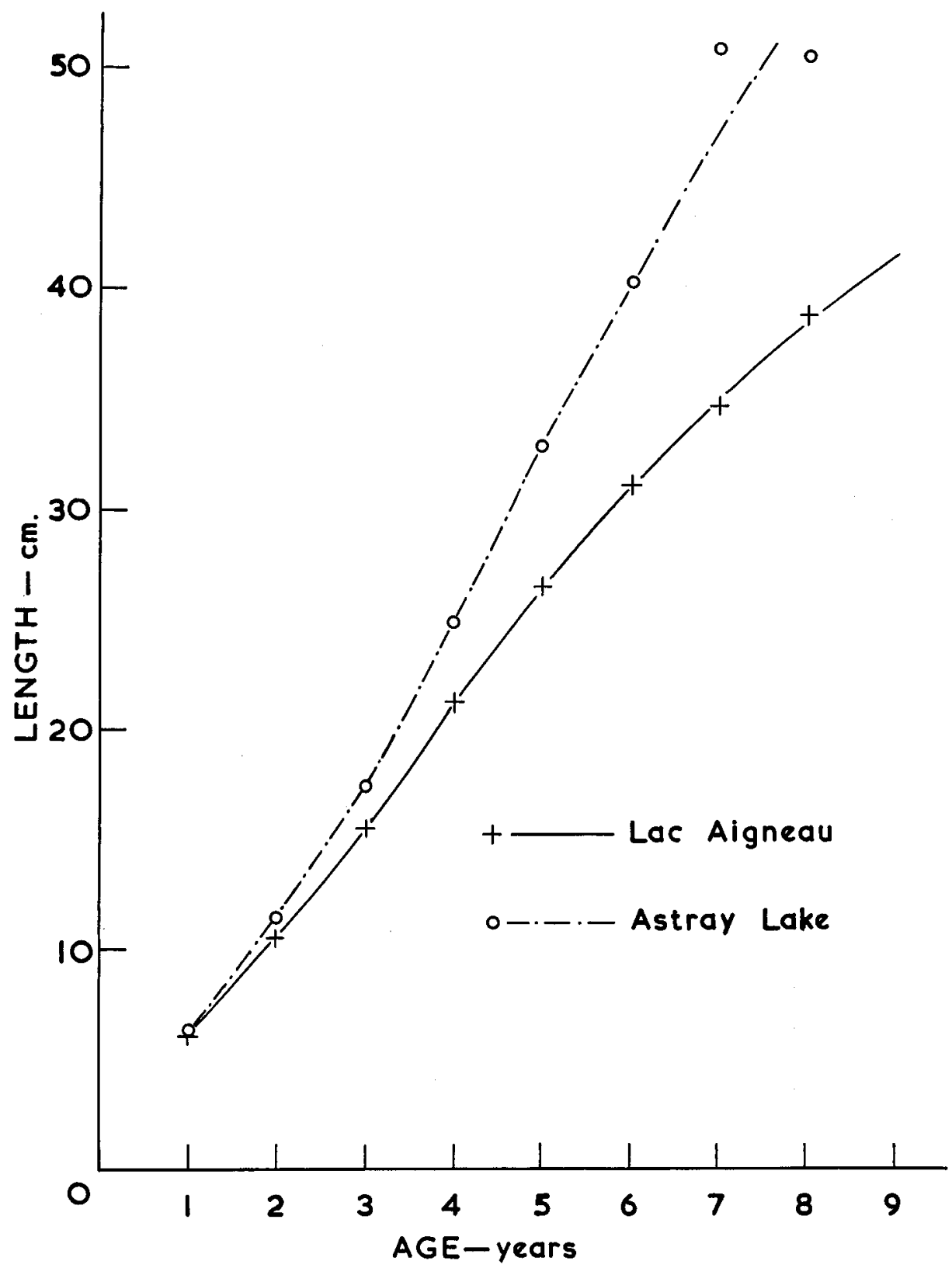

Fig. 1. Growth curves of two freshwater salmon populations.

which the Ouananiche was first described, a marked change in growth rate between pre- and post-smolt stages of the life cycle can be distinguished on the scales. Farther south, where the Sebago salmon are found, this change in growth rate after smolt metamorphosis is so clearly defined that scales of Sebago salmon can be confused with scales from sea-going salmon. 
It appears that a gradual transition exists between the forms found in the extreme northern part of the area and those found in the southern part. The apparently different growth patterns are the result of the differences in length of the growing season and in the amounts and type of food available. The numerous isolated populations of freshwater salmon, distributed over the entire range from north to south, form a cline and therefore ought not to be considered as two separate subspecies, but rather to represent an assemblage of variable forms, which can be distinguished from the parent form by loss of the marine phase of the life cycle.

The condition found in the salmon is thus very similar to that which exists in its near relative, the European trout. The various extreme types of this are represented by the brown trout of the rich, slowly flowing rivers of the plains and the mountain trout of the cold, rapid mountain streams. The sea-going phase, the sea trout, is quite different again, being distinguishable from the others because of its habit of migrating to the sea for part of its life cycle. These extremes are all considered to be varieties of one very plastic species, Salmo trutta (L.), which are morphologically indistinguishable from one another.

The hypothesis outlined in this paper regarding the evolution of the freshwater salmon is intended merely to serve until further data can be collected. Such data should allow separation of the physiological factors concerned with migration from those concerned with reproduction and also an appraisal of the effects of severely cold climatic conditions on these two phenomena.

Table 1. The growth of Ouananiche from Lac Aigneau

\begin{tabular}{|c|c|c|c|c|c|c|c|c|}
\hline \multirow{2}{*}{$\begin{array}{c}\begin{array}{c}\text { Number of } \\
\text { specimens }\end{array} \\
\\
3 \\
6 \\
8 \\
4 \\
2 \\
\end{array}$} & \multicolumn{8}{|c|}{$\begin{array}{l}\text { Calculated mean length in centimetres on the } \\
\text { completion of each winter band }\end{array}$} \\
\hline & $\begin{array}{l}1 \\
6.2 \\
5.5 \\
6.1 \\
6.3 \\
7.0\end{array}$ & $\begin{array}{r}2 \\
9.8 \\
9.6 \\
10.6 \\
11.4 \\
12.0\end{array}$ & $\begin{array}{c}3 \\
14.8 \\
14.7 \\
15.6 \\
16.4 \\
17.5\end{array}$ & $\begin{array}{c}4 \\
20.3 \\
20.1 \\
20.7 \\
23.1 \\
24.0\end{array}$ & $\begin{array}{rc}5 & 6 \\
25.7 & 29.5 \\
25.3 & 30.4 \\
26.5 & 32.1 \\
28.7 & (31.6 ; 5+) \\
(27.0 ; 4+) & \\
\end{array}$ & $\begin{array}{c}7 \\
34.0 \\
34.9 \\
(34.4 ; 6+)\end{array}$ & $\begin{array}{r}8 \text { ye } \\
38.7 \\
(37.5 ; 7+)\end{array}$ & $\begin{array}{l}\text { ears } \\
(39.8 ; 8+)\end{array}$ \\
\hline otal 23 & 6.1 & 10.5 & 15.5 & 21.2 & 31.0 & 34.6 & 38.7 & 39.8 \\
\hline
\end{tabular}

Table 2. The growth of Ouananiche from Astray Lake

\begin{tabular}{ccccccccc}
\hline $\begin{array}{c}\text { Number of } \\
\text { specimens }\end{array}$ & \multicolumn{7}{c}{$\begin{array}{c}\text { Calculated mean length in centimetres on the } \\
\text { completion of each winter band }\end{array}$} \\
\hline & 1 & 2 & 3 & 4 & 5 & 6 & 7 years \\
2 & 6.4 & 11.5 & 17.0 & 24.0 & 31.5 & 38.4 & 45.4 & $(50.5 ; 7+)$ \\
2 & 7.4 & 11.9 & 19.3 & 27.1 & 40.3 & 49.3 & $(56.3 ; 6+)$ \\
4 & 6.6 & 11.5 & 18.8 & 26.2 & 33.1 & $(38.6 ; 5+)$ & \\
7 & 6.1 & 11.2 & 16.6 & 23.9 & $(30.8 ; 4+)$ & & & \\
3 & 6.2 & 11.2 & 16.0 & $(24.0 ; 3+)$ & & & \\
\hline Total 18 & 6.3 & 11.4 & 17.4 & 24.8 & 32.8 & 41.2 & 50.8 & 50.5 \\
\hline
\end{tabular}

In the calculation of the means in Table 2 the figures in brackets () have been included as representing a full year's growth since they represent measurements of specimens collected in September, at the end of the growing season. 
Meanwhile, it seems that mere physical isolation does not suffice as explanation of the present distribution and characteristics of the freshwater salmon of eastern North America. Physical isolation has occurred in some cases that no one would dispute; however, since many of the freshwater populations now have access to the sea but do not take advantage of it, a physiological as well as a physical cause is necessary to explain all the facts.

I wish to thank McGill University, the Arctic Institute of North America, and the Department of Fisheries, Quebec for the financial assistance, which enabled me to carry out this work, and also D. R. Oliver for collecting the specimens from Astray Lake.

\section{References}

Flint, R. F. 1952. The Ice Age in the North American Arctic. Arctic 5:135-52.

Fontaine, M. 1954. Du déterminisme physiologique des migrations. Biol. Rev. 29:390-418. Greeley, J. R. 1948. Four years of landlocked salmon study. Fish and Wildlife Inform. Bull. No. 2. State of New York Cons. Dept.

Hoar, W. S. 1953. Control and timing of fish migration. Biol. Rev. 28:437-52.

Huntsman, A. G. 1944. Why did Ontario salmon disappear? Trans. Roy. Soc. Can. (V), Ser. 3, 38:83-102.

Jordan, D. S. and B. W. Evermann. 1896. The fishes of North and Middle America. A descriptive catalogue of the species of fish-like vertebrates found in the waters of North America, north of the isthmus of Panama. U.S. Nat. Mus. Bull. 47, Pt. 1:486-7.

Low, A. P. 1895. Report on exploration in the Labrador Peninsula along East Main, Koksoak, Hamilton and other rivers. Ann. Rep. Geol. Surv. Can. N.S. 8 (L), 387 pp.

Menzies, W. J. M. 1949. The stock of salmon, its migrations, preservation and improvement. London: Edward Arnold. 96 pp.

Wilder, D. G. 1947. A comparative study of the Atlantic salmon, Salmo salar Linnaeus, and the lake salmon, Salmo salar sebago (Girard). Can. J. Res., D, 25:175-89. 